\title{
DIVERSITY MANAGEMENT AS A KEY FACTOR IN THE REGIONAL DEVELOPMENT PROCESS
}

\author{
AnNA WZIĄTEK-STAŚKO ${ }^{1}$ \\ Silesia University (Poland) \\ Sustainable development strategy does not stand a chance without commitment of the HR department-many people \\ are not aware how many issues are handled by these departments
}

(Kuraszko, 2012).

\begin{abstract}
Economy operates in a broader social system, composed of households and enterprises but also by all institutions created by people. Law and politics is created and introduced in institutions in parallel to educational, administrative activities as well as any other social activities, including those related to the natural environment we live in. These institutions operate thanks to the social capital i.e. interconnected human resources. The quality of the social capital is dependent on mutual trust and relations in the society. For this reason, social capital is of key importance for sustainable development, both as a controller of the impact of the economy on the environment as well as the basis for the future development. The environment evolves continuously, there are rapidly changing economic processes and, in consequence, their impact on the environment is changing rapidly, tool. This brings some specific challenges to the resource and quality of human knowledge and the competence level of the human capital, as the only tool for a possible reduction of all imperfections.
\end{abstract}

KEYWORDS: diversity management, regional development, human capital.

JEL CODES: M12, M14, Q56

\section{Introduction}

Integration of three areas: the economy, society and environment are the key challenges to the contemporary world. However, it is not an easy task because each of the areas evolves continuously. Although seemingly clear, this thesis is definitely more convincing at the theoretical level and more difficult when put into practice. According to Jan Sendzimir: "More often solutions are chosen which ensure fast economic or political profit and lead to instant effects. Compared to such solutions, the sustainable development concept and an integrated and long-term approach related to the concept may seem insufficiently precise and concrete. Introduction of sustainable development faces an additional challenge i.e. change of our habits, related to the existing social structures (institutions), psychological structures (convictions) and physical structures (the infrastructure). Sustainable development requires a change in conceptual models which limit us and a skill to look at things with a fresh eye. We often refrain from using innovative tools and methods because of inertia and thinking patters (...), as ideas rooted in the outlook that caused these problems cannot solve them" (Kronenberg, Bergier, 2010: a part of the Introduction). The author notices with a concern that, unfortunately, the currently effectively economic growth paradigm continues to dominate the development concept, though

Anna Wziątek-Staśko - Adiunkt Uniwersytetu Śląskiego, Ph.D. Scientific interests: diversity management, HRM, innovations, gender.

E-mail: awziatek-stasko@wp.pl, anna.wziatek-stasko@us.edu.pl

Tel.: +48 $323493801,0606589373$. 
its side effect destroys the society and the environment and contribute to a climate change. However, there is also another important issue: we need to change our way of thinking in order to consider the role of people in regional development management process, with a particular emphasis to their variety.

Object of research - human capital vs. sustainable development.

Purpose of research - emphasising the role of diversity management strategy in improving the regional development process. Human capital is a key factor in the management process. Organisation with a human face, organisation socially responsible, ethical organisation... these are the terms, which more and more often accompany considerations about contemporary business. Increasing lack of acceptance for negative effects of activity leaded by enterprises of $21^{\text {st }}$ century (contamination of environment, pathologies in the areas of HRM, corruption and unethical behaviours towards market partners and customers), gave rise to necessity of deeper analysis of the ethics' essence, especially in the context of treating it as a tool of creating contemporary organisation image, particularly responsible organization.

This paper is an attempt to answer the following questions:

- How does the idea of Corporate Social Responsibility (CSR) fit into the sustainable development concept?

- Why does human capital play an important role in the process of regional development improvement and how to engage employees in environmentally-friendly practices?

- Why personnel diversity and skilful personnel diversity management may influence effectiveness of sustainable development strategy?

\section{CSR as expression of an organisation's care for sustainable development}

The contemporary approach to the issue of CSR seems as importance and interesting as ambiguous in interpretation and practical implementation (Berenbeim, 2006: 501), (Waldman, Siegel, 2008: 117-120). According to Peter Drucker, organisations in a society of organizations are special purpose bodies. Each organisation is good in one task only and their specialization gives them the opportunity to fulfil their tasks. Organisations may be harmful to themselves and to the society if they embark on tasks outside their specialized competences, values and their specialized function. The above-mentioned author undermines an argument brought forward by M. Friedman, a Noble Prize winner, that business is responsible only for economics of its operation. Operational economics is the first responsibility of business. Business which does not generate a profit or at least does not break even is socially irresponsible. It is a waste of social resources. However, it is not the only corporate responsibility component, according to Peter Drucker. A particular importance should be attached to POWER. The powerful must demonstrate exceptional responsibility, as power without responsibility is TYRANNY. In the light of the above, it should be required at all times that organizations and corporations are responsible (Drucker, 1999: 86; Swanson, 2008: 231). Responsible business is a strategic and long-term approach, based on the principles of a social dialogue and search for solutions beneficial to everyone. Responsible business is a result of ethical leadership, as claimed by (Tumasjan, Strobel, Welpe, 2011: 609-622; Avolio, Walumbwa, Weber, 2009: 421-449; Toor, Ofori, 2009: 533-547).

Corporate Social Responsibility (CSR) has become one of important issues on which contemporary enterprises focus. Still, it is long before the topic occupies a central position in corporate strategies (Smith, 2003: 52-76; Steward, 2006: 14). It is also caused by lack of awareness as to the essence of the CSR (Porter, Kramer, 2006: 78-92), as it may be evidenced by many definitions of the term. Typically, Corporate Social Responsibility is a concept which helps enterprises, at the stage of building their strategy, to take social interests and environmental protection as well as relations with different stakeholders' groups, into account voluntarily. In other words, corporate responsibility is an effective management strategy. Thanks to social dialogue it keeps at the local level, it contributes to growing corporate competition at the global level while creating conditions in support for sustainable social and economic development. Typically, CSR is described as "corporate citizenship, ethics, stewardship or sustainable development" (Laszlo, 2008: 34). A similar line of thinking on the CSR was also presented in works by other authors (Dahlsrud, 2008: 1-13; Hess, Rogovs- 
ky, Dunfee, 2002: 110-125; Seifert, Morris, Bartkus, 2003: 195-211; Brammer, Millington, 2004: 268-294). Some authors tend to be more focused on the internal dimension of the CSR (human approach to the staff, friendly work conditions, and ethical behavior), other point to its external dimension (positive image, economic benefits to different groups of stakeholders) (Kormancova, 2011: 44-46). Other academics attempt to merge both areas and the concept seems the most reasonable. Irrespective of the number of proponents of each concept, it is worthwhile to be a socially responsible corporation as the "human face" of an enterprise may bring many corporate benefits:

- Increasing interest of investors_- creditors are more interested in cooperation with proper companies, which apart from good financial results, managed in a transparent way, responsibly build their image and good relations with environment. For many investors financial credibility of the company is depended on its social credibility.

- Increasing consumers and stockholders loyalty - consumers' growth of social awareness causes that in making choices they consider trust for a given company and its image. Growing group of consumers pays attention to ecologicalness of the product or service, complying with the rule of social responsibility in the process of its creation and general reputation of the company.

- Improving relations with community and local authorities - company share in local community life, taking long-term and rational social investments makes it easier to operate efficiently and peacefully. Social responsibility enables permanent inveteracy in community and gaining its citizens favor and trust of local authorities.

- Growing competiveness - introducing rules of responsible business is one of advantages, due to which companies get competitive supremacy.

- Improving organizing culture in the company-via taking challenges of social responsibility, company improves its standards of proceedings towards stockholders (employees, partners and customers), this way it avoids costs of bad partnership. These changes influence shaping organizing culture of the company based on trust, responsibility and transparency for all interested parties.

- Gaining and keeping the best employees - when the company's image improves and employees trust increases, company becomes more attractive on the labour market, which allows attracting new and keeping best employees.

- Shaping a positive image of the company among employees - social responsibility of the company constitutes one of the elements of non-financial employee motivation. Thanks to ethical codes, social programmes, caring for environment, the company's image in employees eyes is improved. Employees appreciate company functioning more if its partial activity is directed to solving essentialalso for them - social problems (Wziątek-Staśko, 2009: 117-120).

According to Deloitte, issues related to the CSR and sustainable development should be included in the agenda of management board meetings globally. This thesis is not based on rightful thinking. While altruism may be noble, it is an insufficient a basis for a business (unlike in the case of NGOs or national governments). Deloitte believes that CSR and sustainable development is one of the fundamental areas in corporate activities. Companies which do not engage actively in CSR-related actions may find themselves doomed to a failure (http://obszarcsr.wordpress.com/2011/02/24/csr-i-zrownowazony-rozwoj - 10.05.2012). According to Deloitte's experts: "A mature approach to the CSR brings more significant benefits than self-satisfaction resultant from engagement in charity work or environmental protection activities. A correctly defined strategic approach to the CSR may support the process of continuous business improvement, attract talents, promote a positive image, improve company's operational transparency, improve compliance procedures, inspire partners in the chain of supply, attract investments, prompt stakeholders to action, increase competition and improve the financial result" (2011 Deloitte's report). A list of benefits is long.

Year on year, the number of companies running their social programmes are going up. These are both FMCG companies and manufacturers. Corporate responsibility programmes are also implemented in steelworks, which occupied a prominent position in influencing natural environment. Examples of steelworks' 
activities, such as e.g. ArcelorMittal Poland are analysed as case studies (Gajdzik, 2012: 352), and reports on social activity are available on their websites (www.arcelormittal.com)

\section{Simulation of Employee Behaviour Aimed at Achieving Sustainable Development}

Corporate Social Responsibility cannot be achieved without socially responsible employees. It is not sufficient that an organization decides on entering the path of social responsibility. It is only a start of a difficult journey. The key issue is for the company's management board and its management to be truly convinced about effectiveness of the CSR concept and spreading this conviction on all other employees. Dissemination of the concept should go beyond a list of recommendations or a code of ethical conduct towards other staff and the environment. The best method is to give an example by acting. People are sustainable development creators and, at the same time, participants of the process.

In contemporary economy, one of corporate success factors is creation of an open organization were employees can share and exchange their opinions and ideas, including specifically, their ideas and opinions on sustainable business. Each employee's opinion on methods for running a sustainable business or sustainable development opportunities affects setting future goals of the company. An open organisation is guided by the concept of transferring more power and independence onto employees. Open organisations tend to be more flexible, creative and sustainability-capable (Gajdzik, 2009: 766-771).

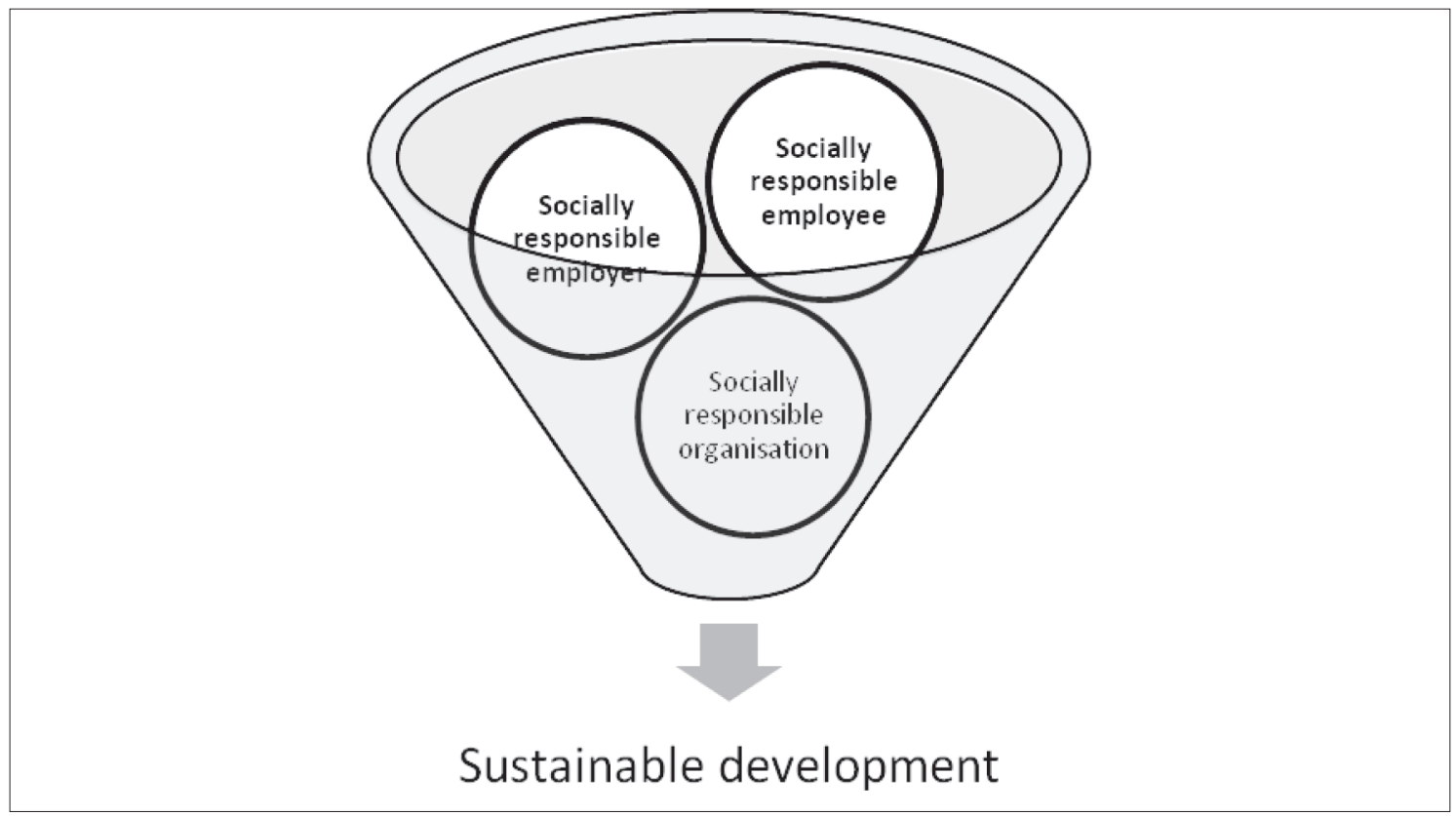

Figure 1. Sustainable development creators

Source: own study

Employer's reliability and integrity towards employees, fair rewarding, appraisal and promotion, compliance, loyalty, openness to employee problems (including personal issues), car for work conditions and modern tools at work, credible and reliable communication - these are only some examples of socially responsible employer's behavior in dealings with the staff. Identification with the company, care for the work place, fair and responsible approach to responsibilities at work, care for company's assets, punctuality and integrity, care for company's positive image, good personal relations, self-improvement - these are only some examples of what a socially responsible employee can offer to his employer. Joint efforts of them both will lead to creating a socially responsible organization. Certainly, interorganisational actions are just the first 
step towards building sustainable development. The next step will involve stepping outside the organisation, with strongly extended circle of stakeholders: clients, vendors, suppliers, the media, and banks, NGOs and local government agencies, business organisations and the general public. Employees should be aware of all green and community-supporting campaigns and actions of the business because then can have an important contribution to their effectiveness.

In many companies, methods were developed to engage the staff into projects by taking joint actions and promoting environmentally-friendly behaviour. In the research run in 2007 and 2008 by the Society for Human Resource Management focused on analysing environmentally friendly character of work places, respondents - employees of HR departments, listed the following best green practices:

- Availability of recycling programmes for stationary and office materials (plastic, glass, cans, polystyrene foam;

- Use of energy-efficient lights and equipment e.g. presence controls, Energy Star certified equipment, laptops instead of PCs;

- Installation of automatic equipment shut-offs;

- procurement and leasing of consumables e.g. tones, Xerox machines, printers, faxes, treaded tires and double-refined oil;

- Promotion of walks, cycling and public transport;

- Collaboration with green trade partners and businesses;

- Reduced pollution in the production process e.g. emission of pollution to water and air;

- Participation in or financing local projects and initiatives such as tree planting and fund raising for environmental protection;

- Two-sided copying and printing;

- Use of energy-saving bulbs in office lamps;

- Pulling down blinds in the summer to save energy;

- Shutting unused computer off.

Sustainable development pays. According to 2007 research of Grant Thornton LLP, an USA-based audit company, a growing number of managers (of 500 in total), sustainable development may have a positive impact on their businesses and achievement of their strategic goals. Sustainable development means company's capability to generate profits without sacrificing human, local or natural resources. According to the research, the highest benefits from programmes and strategies based on sustainable development principles include: a positive impact on the public opinion and customer relations as well as attracting new staff and long-term employment history. As a result, $77 \%$ of respondents plan to increase their investment into environmental programmes (Kuraszko, http:// odpowiedzialnybiznes.pl/p1/baza-wiedzy/publikacje/artykuly/zrownowazony-rozwoj-a-kapital-ludzki, 2094.html - 30.04.2012).

\section{Diversity Management as a part of CSR - an important determinant in the process of building sustainable development.}

In the context of this paper, diversity management and its role in the processes deserves a particular attention among many aspects creating the image of a contemporary organization, which builds its social responsibility. Diversity management is about "noticing differences between people in (and outside) an enterprises and conscious development of strategies, policies and programmes which create a climate for respecting and using the differences for the benefit of the organization. Different people have different needs and the key issue is to be able to identify them in the right way" (Durbin, Lovell, Winters, 2008: 400). Diversity management is about creating such a work environment where each employee (irrespective of their sex, age, education, race, origin, sexual orientation, ability or disability, etc.) feels appreciated and respected and where can fully achieve their potential, which contributes to the organization's success and is an expression of the organisation's social responsibility. 


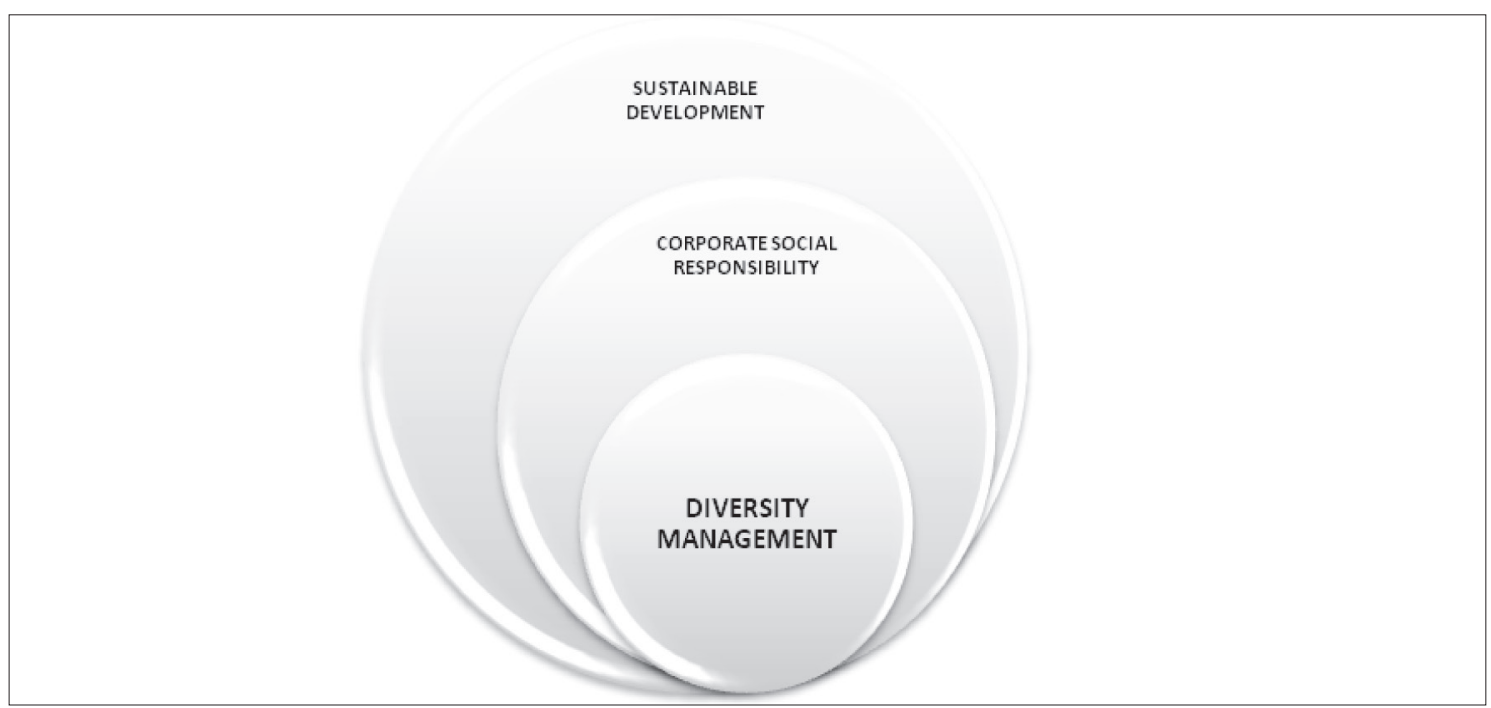

Figure 2. Sustainable development circle

Source: own study

Actually, very few researchers have made the effort to analyse the impact of implementing the diversity management strategy in an organisation on its employer's branding and the degree of its perception as a socially responsible one. It is even more difficult to analyse a relation between this strategy and a broadly understood sustainable development concept. The interdependency should be more assessed as intuitively perceived. It is likely that such perception results from lack of sufficient knowledge both on diversity management and on the essence of social responsibility among entrepreneurs, which creates a substantial difficulty when operationalising the dependency.

The answer to "diversity around an organization" (different stakeholders: clients, suppliers, shareholders, wholesalers and retailers, local communities, NGOs, state and local government agencies and their various interests) must be "diversity in an organization" (different employees and their proper management) as a method to optimize the degree of satisfying needs of both groups. A "responsibility-oriented" enterprise is an enterprise that responds positively to expectations of differentiated environment, institutions and people who form it. An enterprise is a collection of interests of those who are inside and outside the enterprise. Its survival requires meeting of stakeholders' expectationns in the economic and social area. It is the degree of satisfying stakeholders' expectations which determines the extent of social responsibility of a company and its CSR status. According to (Bear, Rahman, Post, 2010: 1-3), businesses with women prevailing on their boards, are more charity-prone and support creation of friendly work environment and, as emphasised by authors, are more socially responsible. However, this interdependency is difficult to be unequivocally confirmed and requires continuation of the analytical processes. However, irrespective of the sex of the organisation's leaders, they must be "socially responsible". The present makes leaders face increasing challenges and requirements and it is not only a result of a struggle with unethical behavior in business and an attempt to eliminate many scandals. Reality and problems of 21 st century world force organisations to change (poverty, degrading environment, fight for human rights, employee rights, diseases such as AIDS) (Pless, Maak, Stahl, 2011: 238; Haugh, Talwar, 2010: 384), and terrorism on top of that.

Organisations operating in a global environment must also act "global". For example, ArcelorMittal Group, being the largest steel producer in the world treats mergers and acquisitions as the main strategic direction of the group. All the transactions are executed by the group of experienced and tested managers who usually fill the top managers' positions in the new ventures. Gradually they move to the other plants being the parts of the corporation (Sroka, 2009: 62). In this context, the priority should go to a new way of looking 
at management, a growing need to improve organisation's flexibility, the ability to analyse the elements of its micro- and macro-environment in a comprehensive manner, a serious approach to human diversity. It is not an easy task. Many find diversification troublesome as most people prefer to operate on the basis of widelyheld, well-proven patterns and operational procedures. The economic crisis experienced by many economies in the world, including economies in the largest countries, may have been an outcome of the omnipresent ignorance and self-confidence of "socially irresponsible" decision-makers. Contemporary enterprises should care to implement diversity management strategies as it is the leading determinant of their responsibility and the only path leading to building a socially responsible world.

\section{Advantages of diversity management}

Well-planned and implemented with conviction, diversity management many generate a number of measurable benefits to an organisation (Allen, Dawson, Wheatley, White, 2008: 20; Chavez, Weisinger, 2008: 331). Leading strengths of diversity management include:

- An impulse to come up with new ideas and achieve excellence in one's attitude towards work.

- Enhanced adaptability of an organisation.

- A bigger pool of options for internal recruitment.

- A broader base for creating the core of company's skills.

- More extensive opportunities of HR reconfiguration supporting selection of an optimum management strategy.

- A possibility of a more accurate work division and mutual replacement of employees thanks to complimentary qualifications.

- A bigger pool of potential company's representatives to participate in negotiation processes.

- Increased knowledge resources of an organisation.

- Support for introducing the concept of a learning organisation, reduced monotony.

- Possibility to make more accurate decisions.

- Reduced distance to working out the best solutions thanks to an exchange of experience and ideas of diversified staff.

- Smoother process of overcoming resistance to changes - costs of lost opportunities resulting from abandoning some activities as well as other costs e.g. costs of staff turnover (unhappy staff leaving) can be calculated.

- An easier access to the talent base - a more open environment attracts more talented and more creative persons who hope to be able to put their ideas into practice. The skills of using the talent diversity influences maximisation of company's profits.

- Improved work atmosphere - good atmosphere at work, with people open, outgoing, appreciated and respected enhances their commitment and effectiveness. An employee who feels important and valuable, whose work is appreciated and considered in case of promotions is more committed.

- Creating the atmosphere of cultural sensitivity and mutual tolerance.

- Enriching employees - employees influence one another, they work and operate in a diversified environment - it is an opportunity to learn from one another.

- A more extensive network of colleagues.

- Faster and more frequent finding opportunities in the environment.

- Improved company's image and reputation - it is not only the issue of CSR but mostly the issue of the internal and external PR. It is also an opinion of an excellent employer - employer by choice. Such brand and name will attract the most talented graduates. Satisfied staff working in a friendly atmosphere, non-discriminated and respected, is the best tool building reputation and image of a trustful company among its future employees, clients and business partners.

- More effective management of an organisation - selection of management tools (recruitment and selection, motivation, career path, evaluation, leadership style, etc.) accounting for diversity of employee 
helps to reduce the risk of a failure thus reducing the precious time required to reach the end result intended by the employer. In the light of the above, note that effective use of these tools depends both of competences of employees to whom they are applied and on competences of those who use them. The material was collected and edited on the basis of: A. Lipka (2004: 279-281); Raport "Firma=Różnorodność. Zrozumienie, poszanowanie, zarzqdzanie" (2009: 23-24), A. S. Bachmann (2006: 721-747), J. N. Cummings (2006: 352-364), S. K. Horwitz, I. B. Horwitz (2007: 987-1015), M. E. A. Jayne, R. L. Dipboye (2004: 409-424). It's worth of considering and doing because personal development is a key determinant of the organizational development, this of the regional development and in the end-global development. Below find a graphic presentation of the interdependency (Figure 3).

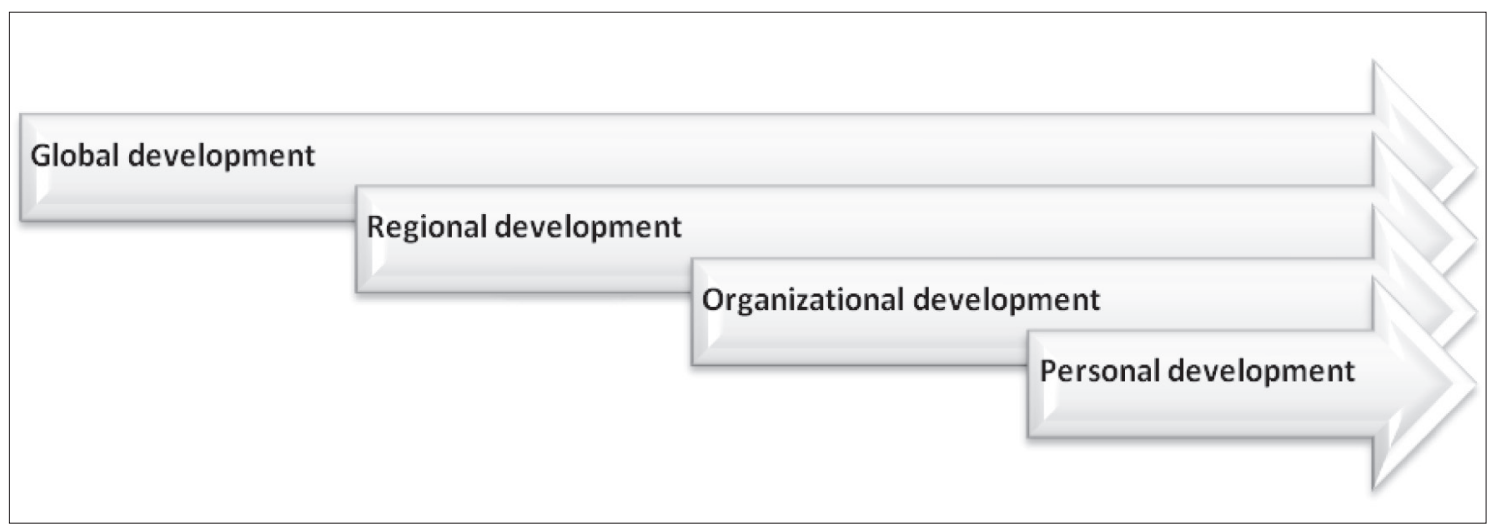

Figure 3. From personal development to global development

Source: own study

\section{Conclusions}

This paper has been written to address and emphasise the interdependency noticed between a skillful HR management in an organization and a sustainable development concept.

Diversity management is based on a close relation between personnel, organisational culture and degree, to which the company's mission is achieved. It applied to an invisible and often informal dimension of enterprise's operation i.e. organizational culture (shared values, standards, convictions, habits as well as widely-held ways of thinking and behaving). It is an innovative personnel management strategy and it comes as the top level of deliberation over the role of a man in an enterprises (Wziątek-Staśko, 2012: 24), creating the real opportunity to optimize process flow effectiveness of many business processes. The strategy gains a particular importance when applied in a sustainable development concept.

Note that there are some paradoxes in management. On the one hand, employees are expected to deliver the best performance and, on the other hand, organizations cannot get free from pathologies such as: discrimination, lobbing, corruption, nepotism which has a destructive impact on work efficiency and people's private lives. On the one hand, organisations declare ethics its essential value and, on the other hand, they break the law by violating rules. On the one hand, businesses declare their social responsibility and, on the other, they operate on the basis of procedures which are not always clear. There are many such paradoxes. Why do they exist? They exist, because insufficient effort was put in making employees understand consequences of such approach. Or maybe managers do not have this awareness?

Social and economic aspects were always in juxtaposition. What is socially desirable, it is unfortunately often not effective in the economic sense. Business effectiveness, on the other hand, often means limitations to the social sphere. In addition, the complexity of the relation is increased by the need to care for the environment. One must admit that this is a real challenge for the world and human mentality to care for 
sustainable development. Actions should be based on small steps, starting from caring about the key issue awareness of people - employees. Without full commitment of its creators, no project which expresses care for sustainable development is going to be successful. One may make the effort to build the commitment through understanding, acceptance and use of an innovative HR management strategy in an organisation i.e. diversity management.

\section{References}

Allen, R., Dawson, G., Wheatley, K., White, C. (2008). Perceived diversity and organizational performance. Employee Relations, Vol. 30(1), p. 20.

Avolio, B. J., Walumbwa, F. O., Weber, T. J. (2009). Leadership: current theories, research and future directions. Annual Review of Psychology, No. 60, p. 421-449.

Bachman, N. A. S. (2006). Melting pot or tossed salad? Implications for designing effective multicultural workgroups. Management International Review, Vol. 46, No. 6, p. 721-747.

Bear, S., Rahman, N., Post, C. (2010). Diversity drivers: how gender composition and director resource diversity affect corporate social responsibility and reputation. Academy of Management Annual Meeting Proceedings, p. 1-6.

Berenbeim, R. E. (2006). Business ethics and corporate social responsibility. Vital Speeches of the Day, No. 72, p. 501-503.

Brammer, S., Millington, A. (2004). Stakeholder pressure, organizational size and the allocation of departmental responsibility for the management of corporate charitable giving. Business \& Society, Vol. 43(3), p. 268-294.

Chavez, C. I., Weisinger, J. Y. (2008). Beyond diversity training: a social infusion for cultural inclusion. Human Resource Management, Vol. 47(2), p. 331.

Cummings, J. N. (2004). Work groups, structural diversity and knowledge sharing in a global organization. Management Science, Vol. 50, No. 3, p. 352-364.

Dahlsrud, A. (2008). How corporate social responsibility is defined: an analysis of 37 definitions. Corporate Social Responsibility and Environmental Management, Vol. 15(1), p. 1-13.

Drucker, P. F. (1999). Społeczeństwo pokapitalistyczne. Warszawa: PWN, p. 86.

Durbin, S., Lovell, L., Winters, J. (2008). Professional insights diversities in an organizational context. Equal Opportunities International. Emerald Group Publishing Limited 0261-0159, Vol. 27, No. 4, p. 400.

Gajdzik, B. (2009). Poziom zaangażowania pracowników w przedsiębiorstwie hutniczym. Hutnik-Wiadomości Hutnicze, Vol. 76, No. 10, p. 766-771.

Gajdzik, B. (2012). Przedsiębiorstwo hutnicze po restrukturyzacji. Dynamika zmian w krajowym sektorze hutniczym w latach 1992-2001. Politechnika Ślaska (Monografia). Gliwice.

Haugh, H., Talwar, A. (2010). How do corporations embed sustainability across the organizations. Academy of Management Learning \& Education, Vol. 9, No. 3, p. 384-396.

Hess, D., Rogovsky, N., DunfeE, T. W. (2002). The next wave of corporate community involvement: corporate social initiatives. California Management Review, Vol. 44(2), p. 110-125.

Jayne, M. E. A., Dipboy, E. R. L. (2004). Leveraging diversity to improve business performance: research findings and recommendations for organizations. Human Resources Management, Vol. 43, No. 4, p. 409-424.

Kormancová, G. (2011). Rozvoj l'udského kapitálu v oblasti projektového riadenia. Vedecko-odborný časopis: Ekonomika - Management - Inovace č. Moravská vysoká škola Olomouc, Olomouc, No. 1(3), p. 44-49.

Laszlo, Ch. (2008). Firma zrównoważonego rozwoju. Warszawa: Studio Emka.

Lipka, A. (2004). Metodyka badania stopnia różnorodności potencjału społecznego organizacji. Badania statutowe Katedry Polityki Spotecznej i Gospodarczej na temat: Gospodarowanie potencjatem społecznym w organizacjach, w warunkach wzrostu jego różnorodności. Akademia Ekonomiczna w Katowicach, Katowice [niepublikowany maszynopis].

Pless, N., Maak, T., StahL, G. (2011). Developing responsible global leaders through international service- learning programs: the Ulysses experience. Academy of Management Learning \& Education, Vol. 10, No. 2, p. 237-260.

Porter, M. E., Kramer, M. R. (2006). Strategy and society: the link between competitive advantage and corporate social responsibility. Harvard Business Review, Vol. 84(12), p. 78-92.

Seifert, B., Morris, S. A., Bartkus, B. R. (2003). Comparing big givers and small givers: financial correlates of corporate philanthropy. Journal of Business Ethics, Vol. 45(3), p. 195-211.

Smith, N. C. (2003). Corporate social responsibility: whether or how? California Management Review, Vol. 45(4), p. 52-76.

Stewart, T. A. (2006). Corporate social responsibility: getting the logic right. Harvard Business Review, Vol. 84(12), p. 14.

Sroka, W. (2009). Competitive advantage through cooperation in networks on sector level: the case of steel industry. W: J. Kaluza (ed.). Strategic Management and its Support by Information Systems. VSB - Technical University of Ostrava, p.62-69. 
Swanson, D. L. (2008). Top managers as drivers for corporate social responsibility. W: A. Crane, A. Mcwilliams, D. Matten, J. Moon, D. S. Siegel (eds.). The Oxford Handbook of Corporate Social Responsibility. Oxford University Press, Oxford, p. 227-248.

Toor, S., Ofori, G. (2004). Ethical leadership: examining the relationships with full range dimensions. Academy of Management Journal, No. 47, p. 255-266.

Tumasjan, A., Strobel, M., Welpe, I. (2011). Ethical leadership evaluation after moral transgression: social distance makes in difference. Journal of Business Ethics, No. 99, p. 609-622.

Waldman, D. A., Siegel, D. S. (2008). Defining the socially responsible leader. The Leadership Quarterly, No. 19, p. 117-131.

Wziątek-Staśko, A. (2009). Jakość pracownika i jakość pracodawcy- potrzeba komplementarności. Praca zbiorowa pod red. A. Lipki i St. Waszczaka. Koszty jakości zarzqdzania kapitałem ludzkim a ryzyko personalne. Katowice: Prace naukowe AE w Katowicach.

Wziątek-Staśko, A. (2012). Diversity Management narzędzie skutecznego motywowania pracowników. DIFIN, Warszawa, p. 24.

Website: http://obszarcsr.wordpress.com/2011/02/24/csr-i-zrownowazony-rozwoj/

Report. (2009). Deloitte Polska. Member of Deloitte Touche Tohmatsu Limited: Zarzadzanie ryzykiem. Społeczna odpowiedzialność biznesu i zrównoważony rozwój. Website: www.deloitte.com, p. 8.

Raport. (2011). Firma = Różnorodność. Zrozumienie, poszanowanie, zarzadzanie. Zeszyt 2, Forum Odpowiedzialnego Biznesu. Projekt współfinansowany ze środków Ministerstwa Pracy i Polityki Społecznej w ramach Programu Operacyjnego Fundusz Inicjatyw Obywatelskich. Warszawa, p. 8.

\section{IVAIROVÉS VALDYMAS, KAIP ESMINIS REGIONŲ VYSTYMOSI VEIKS N Y S}

ANNA WZIĄTEK-STAŚKO

Silezijos universitetas (Lenkija)

\section{Santrauka}

Ekonomika funkcionuoja platesnèje socialinèje sistemoje, kuri sudaryta iš namų ūkių ir įmonių bei kitų žmonių įsteigtų institucijų. Teisè ir politika kuriamos ir igyvendinamos institucijose lygiagrečiai su švietimu, administracine ir kita socialine veikla. Šios institucijos veikia socialinio kapitalo, t. y. žmogiškuju išteklių, dèka. Dèl šios priežasties socialinis kapitalas yra esminis darnaus vystymosi veiksnys - tiek kaip kontrolès mechanizmas, tiek kaip ateities vystymosi pagrindas. Aplinka nuolat kinta, kinta ir ekonominiai procesai, taigi ir jų įtaka gamtinei aplinkai. Todèl būtinos atitinkamos žinios ir atitinkamo kompetencijos lygio žmogiškasis kapitalas, nes tik jis gali išspręsti susidariusias problemas.

PAGRINDINIAI ŽODŽIAI: ¿̇vairovès valdymas, regionu vystymasis, žmogiškasis kapitalas.

JEL KODAI: M12, M14, Q56 